\title{
Characteristics and Permeability Properties of Sago Starch Edible Film
}

\author{
Payung Layuk ${ }^{1, *}$, Joula Sondakh ${ }^{1}$, Marietje Pesireron ${ }^{2}$ \\ ${ }^{1}$ North Sulawesi Assessment Institute for Agricultural Technology \\ Jl. Kalasey-Minanga, Malalayang Dua, Kec. Malalayang, Kota Manado, Sulawesi Utara \\ ${ }^{2}$ Maluku Assessment Institute for Agricultural Technology, Jln. Chr. Soplanit Rumah Tiga Ambon, 97234 \\ *Penulis Korespondensi: E-mail: playuk21@gmail.com
}

\begin{abstract}
The research was aimed to study the potential of sago starch as an edible film or edible wrapper, which is used as a barrier to mass transfer. The edible film was made from sago starch with the addition of nutmeg pectin at concentrations of $0 \%, 10 \%, 15 \%, 20 \%$ and $25 \%$ by adding glycerol as much as $20 \% \mathrm{w} / \mathrm{w}$. The results showed that the addition of nutmeg pectin and glycerol was able both to improve film characteristics and to control mass transfer. Addition of nutmeg pectin caused an increase in the Water Vapor Permeability (WVP) value of the film. Edible sago starch films can be used as a dodol packaging material because it protects products from oxidation and fungi, and is a better barrier from oxygen when compared to synthetic films. The increase in nutmeg pectin concentration caused an increase in WVP and exponential oxygen permeability.
\end{abstract}

Keywords: edible film, sago, wrapping

\section{INTRODUCTION}

Edible film or a thin layer that can be eaten and functions by regulating the transfer of water, oxygen, carbohydroxide, lipids, compounds of aroma and taste in food systems, hence increasing the shelf life of food products and improve the quality of food ingredients. Edible films can also reduce the amount of conventional synthetic packaging materials needed to preserve and protect food ingredients while improving packaging recycling capabilities by improving the need for coatings and laminates. Edible film applications for food coatings have been assessed by Kester and Fennema (1985), Gulbert (1986), Krocta et al. (1994), Layuk et al. (2001), and Sunarti and Layuk (2010). There is an excellent prospect of sago starch to be used as a standard for making edible films (Polnaya et al., 2006; Polnaya et al., 2012; Wattimena et al., 2016). Sago yields high starch, which is 20-40 tons of dry starch/ha/year. Sago productivity in producing carbohydrates is higher than corn (5 tons/ha) and cassava (6.25 tons/ha). The production of sago flour is 8.4-13.6 million tons per year in several regions such as Papua, Maluku, Sulawesi, Kalimantan, Sumatra, Riau Islands and the Mentawai Islands (Sayaka, 2016). The potentiality for sago starch as a valuable local product creates an excellent opportunity for it to be used as a source of raw material for making edible films since it is easy to obtain and inexpensive.

The ingredients of edible films are classified into three categories, hydrocolloids, lipids and mixtures. The combination of two types of edible film-forming materials can be formulated to increase the effectiveness of the film as a mass transfer inhibitor by combining strengths and reducing the weakness of each material. Sago starch and nutmeg pectin are considered as hydrocolloid which can be formulated, both in single and combination, to form a good film. The combination of these two materials is expected to produce better quality films.

The study aimed to study the effect of the addition of nutmeg pectin to the sago starch film and to study the characteristics of edible film and its permeability properties. This formulation is expected to optimise the application of edible film in the food industry.

\section{RESEARCH METHODS}

\section{Materials and Tools}

The material used in this study included sago starch taken from the Sangihe archipelago, nutmeg pectin, glycerol, aquadest and silica gel. 
While the equipment used in this research were plastic pan, blender, filter cloth, oven, scales (analytical and rough) magnetic stirrer, water bath, glass mould, plastic mat, plastic sealed container, tensile strength and elongation tester strength stereograph - M1, WVTR tester and microcal Messmer.

\section{Research Procedure}

\section{The Making of Sago Starch}

, there were several processing steps in order to obtain sago starch: sago flour was washed to remove the impurities by adding water in the container until the sago flour submerged and stirred - stirring process was done continuously until the dirt looks floating and then filtered using filter cloth. Let stand for approximately 6 hours until the sago starch settled and every 6 hours the soaking or washing water replaced. This washing process was carried out five times so that it was immaculate until starch deposits cleaned. Sago starch was then dried using a cabinet dryer at a temperature of $50^{\circ} \mathrm{C}$ for 24 hours and then dried sago starch was sifted using 80 mesh sieves (Balitbangan, 2015) with 90\% flour yield passing an 80 mesh sieve (Figure 1).

\section{Isolation of Nutmeg Pectin (Layuk, 2001)}

Ripen nutmeg fruit flesh was washed and cut into $2 \times 2 \mathrm{~cm}$ pieces. The cut was blanched at $95^{\circ} \mathrm{C}$ for 3 minutes to deactivate the enzyme. The nutmeg meat that had blanched was then dried in the sun for 3-5 days until the moisture content reached $10-12 \%$. Dried nutmeg flesh was ground using a miller equipped with 60 mesh sieve. Nutmeg powder packed with plastic and then wrapped in aluminium foil and then stored at $-20^{\circ} \mathrm{C}$ until ready for use. Pectin isolation as shown in Figure 2.

\section{The making of Sago Starch Edible Film}

Sago starch was dissolved in distilled water $3 \%(\mathrm{w} / \mathrm{w})$, then pectin was added with concentration according to treatment $(0 \%, 10 \%$, $15 \%, 20 \%, 25 \%$ and $30 \%(\mathrm{w} / \mathrm{w})$ the mixture was homogenized with a magnetic stirrer, then glycerol was added as much as $20 \% \mathrm{w} / \mathrm{w}$ then put in a water bath at temperature of $70-80^{\circ} \mathrm{C}$ for 30 minutes, the temperature was maintained for 5 minutes, then poured into glass molds that had been given plastic mat, glass was then put in a drying oven at a temperature of $55-60^{\circ} \mathrm{C}$ for 18 hours, then removed from the oven and left to stand for a while at room temperature so it can be easily peeled out. The resulting film was stored in a closed plastic container. Sago starch was stored for four days in a plastic box that had been given silica gel (room temperature).

\section{Sago Flour}

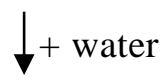

$$
\text { Immersion (6 hours) }
$$
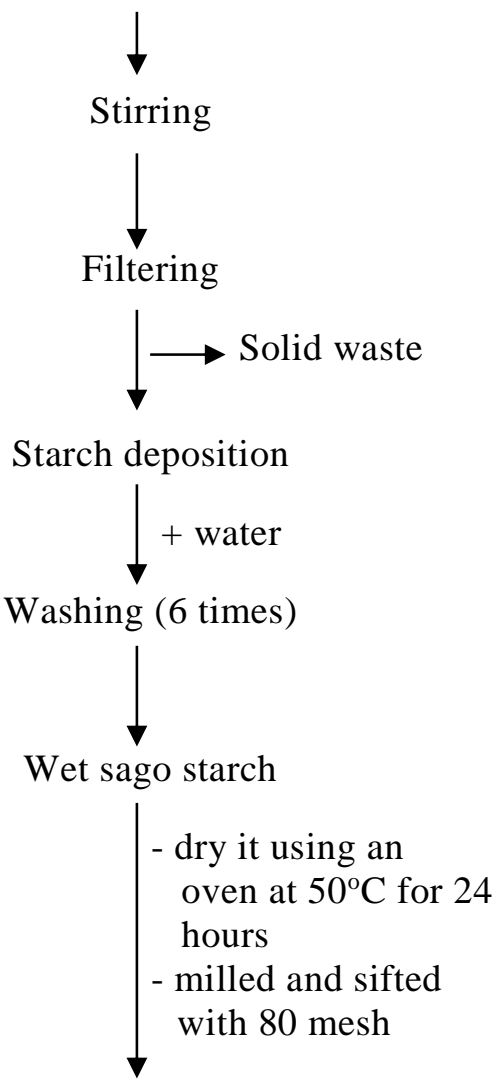

Sago Starch

Figure 1. Flow chart of sago starch extraction

\section{Data observation and Analysis}

The variables observed were the characteristics of edible films, namely tensile strength and elongation, film thickness using callipers, solubility, water vapour and oxygen transmission rates. This study used a single randomised complete design with three replications (Gomez and Gomez, 1984). If there is a significant treatment effect from the results of statistical analysis, a least significant difference test was applied. 
Nutmeg powder

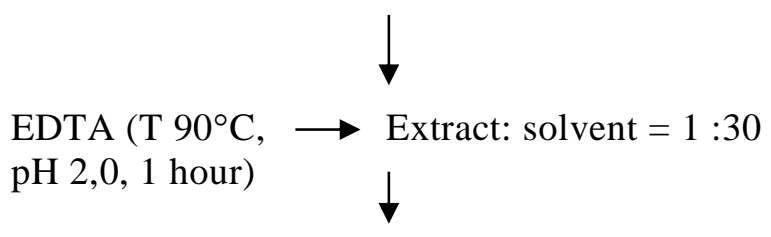

Filtering

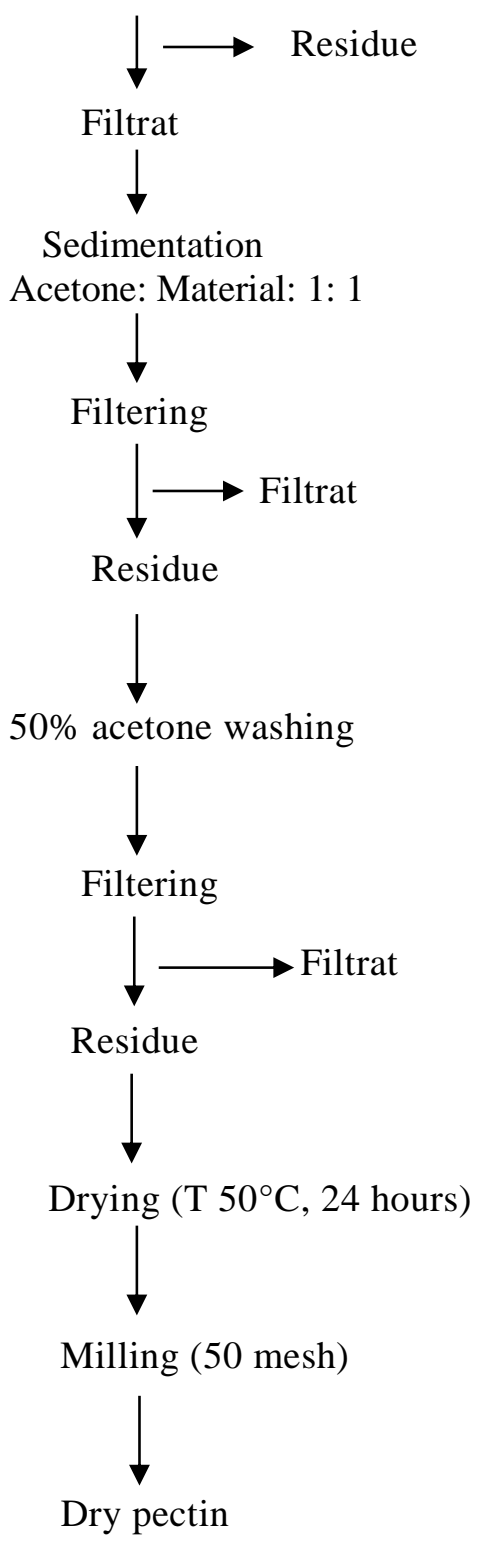

Figure 2. Flowchart of isolation of nutmeg pectin

\section{Analysis of Procedure}

Tensile strength and elongation (Gontard et al., 1992)

Tensile strength and percentage elongation were measured using tensile strength and elongation tester stereograph-M1 Toyoseiki. Before measuring, the film was conditioned inroom $25^{\circ} \mathrm{C}$, RH $50 \%$ for 24 hours. The tool was set on the initial grip separation of $10 \mathrm{~cm}$, the crosshead speed was $50 \mathrm{~mm} /$ minute, and the load cell was $5 \mathrm{~kg}$. Tensile strength was determined based on the maximum load used in the area of the film. The elongation percentage was measured as a percentage of the difference between the final length when the film breaks (torn) and the initial length of the film divided by the length of the film.

\section{Film Thickness (McHugh et al., 1994)}

Film thickness was measured using a microcal mess with an accuracy of $0.0001 \mathrm{~mm}$. Measurements were made in five different places. Then the average of the five edible film measurements was taken.

\section{Water Vapor Transmission Rate (WVTR) (Krohta, 1997)}

The film's water vapour transmission rate was measured by using the WVTR tester. Before measuring, the film was conditioned in a room with a temperature of $25^{\circ} \mathrm{C}$, RH $50 \%$ for 24 hours. The moisture-absorbent (pressure) was placed in a cup so that the surface was about 3 $\mathrm{mm}$ away from the film to be tested. The cup lid was placed face up, and the metal ring was placed so that the regular part was facing up. The film was placed into the cup lid, then the rubber ring was placed for sealing in, closed so that the ring presses on the film. Next, the lid was screwed on the cup. The cup was weighed with an accuracy of $0.0001 \mathrm{~g}$ then placed in the humidity chamber, closed and ran the fan. The cup was weighed every day in almost the same hour and was determined by the weight of the cup. Next, a graph of the relationship between weight gain (mg) and time (hours) was made.

The formula calculates WVTR value:

$$
\text { WVTR }=4,8 \times \frac{m^{2}}{t} \mathrm{~g} / \mathrm{m}^{2} / 24 \text { hours }
$$

explanation: $\mathrm{m}^{2}=$ weight gain $(\mathrm{mg} / \mathrm{t}$ hour $), \mathrm{t}=$ time between the last two weighings (hours)

Calculated the WVTR arithmetic average of WVTR numbers of all tested plates and all of these average figures indicate WVTR numbers obtained in units of $\mathrm{g} / \mathrm{m}^{2} / 24$ hours. 


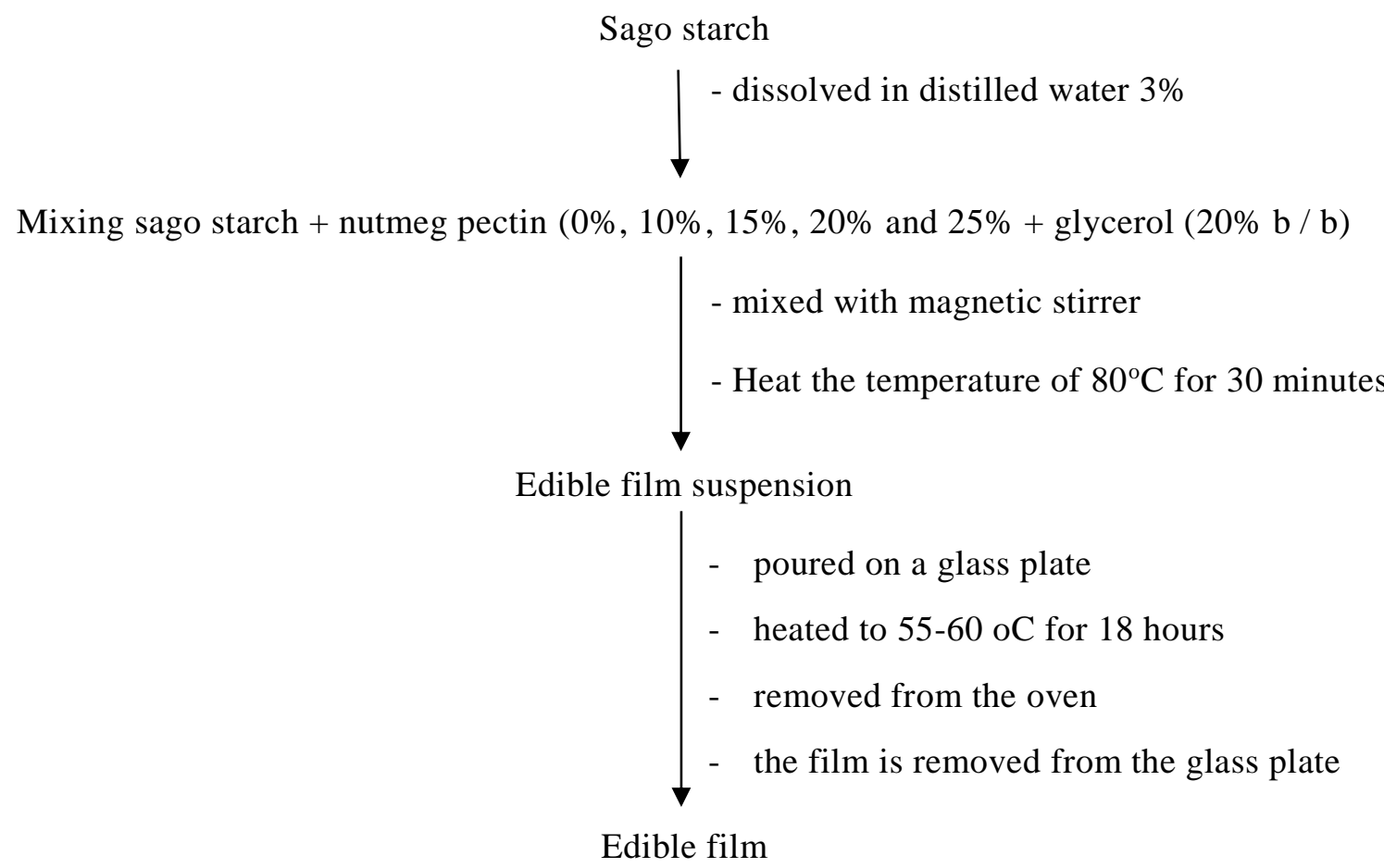

Figure 3. Diagram for making edible films

\section{Oxygen Permeability $\mathrm{O}_{2} \mathrm{P}$}

Oxygen permeability was measured using the OX-Tran 2/20 ml Modular System. The oxygen transmission rate was determined at $23^{\circ} \mathrm{C}$ with $\mathrm{RH}$ conditions varying. The films were inserted in the test cell and contacted with pure nitrogen on one side of the fil and pure oxygen on the other side. The two gas streams were moisturized to the same RH. Aluminium masks were used to reduce the area of the film test area by up to $5 \mathrm{~cm}^{2}$ (ASTM, 1988). The film cracked around the seal when an aluminium mask was not used. Oxygen permeability was calculated by dividing the oxygen flow rate with oxygen pressure and multiplying by the average film thickness.

\section{RESULTS AND DISCUSSION}

The characteristics of edible film sago starch with the addition of nutmeg pectin can be seen in Table 1.

\section{The Thickness of Edible Film}

In Table 1, it can be seen that the higher the concentration of nutmeg pectin added, the thicker the film produced. The results of statistical analysis showed that edible film of sago starch without the addition of nutmeg pectin was significantly different from the addition of pectin. However, the addition of nutmeg pectin with a concentration of $10 \%$ to $20 \%$ did not show significant differences in thickness, except for the addition of $25 \%$. This is because pectin can form or cross the chains of sago starch to form a matrix causing the film to be compact and robust so that the resulting film becomes thick. In other words, the thickness of the film is influenced by the number of solids in the film-forming solution and the thickness of the mould (Layuk, 2001).

\section{Tensile strength and Elongation}

Tensile strength and percent elongation are mechanical properties related to the chemical structure of the film. Tensile strength is defined as the maximum tensile stress, while the extension is the maximum change in length experienced by the film when testing tensile strength in a torn film (Hay, 1968). According to Gontard and Guelbert (1992), the mechanical properties of films depend on the type of film-forming material, especially the nature of structural cohesion. This property is the result of the ability of polymers to form stable molecular bonds. Addition of pectin to film- 
forming solutions with cellulose material can improve the mechanical properties of films (Layuk et al., 2001). Before the addition of pectin, the film from sago starch was brittle, after the addition o nutmeg pectin, the resulting film was stronger and elastic. This is due to the increase in the strength of the molecular chain in the film matrix through the formation of interactions between sago starch, pectin and glycerol so that the film becomes stronger, compact and elastic. Addition of nutmeg pectin also increases the number of carbon groups and functional groups in the matrix chain thereby increasing the percent elongation (Park et al., 1993).

\section{The Solubility of Edible Film}

The easily soluble nature of film in a liquid is one of the determining factors in the selection of films as packaging material. The film solubility decreased with increasing nutmeg pectin concentration. The results of the statistical analysis (Table 1), show that the highest solubility is without the addition of nutmeg pectin. The decrease in solubility caused pectin in the water to form a stronger gel than sago starch hence making it difficult to dissolve in water. The ability of the film to dissolve in water is influenced by the length of the $\mathrm{C}$ chain.he longer the $\mathrm{C}$ chain the more soluble is the film in water.

\section{Water Vapor Transmission of Edible Film}

The hydrophilic nature of sago starch, pectin and glycerol hurt retaining water vapour transmission of the film. According to Banker et al. (1966), the WVTR value of film from sago starch was greatly influenced by time, thickness, the concentration of plasticiser, and film formulation.

The WVTR value of edible films produced ranged from $620.53-852.00 \mathrm{~g} / \mathrm{cm}^{2} /$ day (Table 1).
The addition of pectin to the film solution decreased the WVTR value. This is because the film-forming molecules have a tight arrangement making the water molecules difficult to pass. The nature of pectin which can bind water causes water to be bound to the film but not through the film. Besides, the addition of nutmeg pectin causes the increase in the film thickness so that water becomes difficult to pass through the film but is readily absorbed by the film. They are therefore yielding the negative effect on WVTR films. To improve the transmission properties of water vapour films, the addition of lipids is more effective as a water vapour barrier (McHugh and Krochta, 1994).

The results of the analysis of variance showed that the addition of nutmeg pectin resulted in significant differences in the concentration range of $10-20 \%$ but not significantly statistically different at concentrations of $20-25 \%$.

\section{Oxygen Permeability $\left(\mathrm{O}_{2} \mathrm{P}\right)$}

In Table 1, it can be seen that the edible film of sago starch with the addition of nutmeg pectin concentration had good oxygen transmission (OP) properties. This is because the film from sago starch has a tight and robust bonding network structure (Park et al., 1993). Addition of nutmeg pectin not only improving the mechanical properties of the film, but also improving the OP value of the film (Layuk et al., 2002).

The addition of nutmeg pectin at a concentration of $10 \%$ resulted in films with oxygen transmission properties that were significantly different from other concentrations. This was due to the addition of nutmeg pectin, which increases the density of distances between molecules. Therefore, oxygen becomes challenging to pass, although the OP value is different if analysed, there were no significant differences (Table 1).

Table 1 . The average value of the characteristics of an edible film of sago starch

\begin{tabular}{ccccccc}
\hline Treatment & $\begin{array}{c}\text { Thickness } \\
(\mathrm{mm})\end{array}$ & $\begin{array}{c}\text { Elongation } \\
(\%)\end{array}$ & $\begin{array}{c}\text { Tensile strength } \\
\left(\mathrm{kgf} / \mathrm{cm}^{2}\right)\end{array}$ & $\begin{array}{c}\text { Solubility } \\
(\%)\end{array}$ & $\begin{array}{c}\text { Water Vapor } \\
\text { Transmission } \\
\left(\mathrm{g} / \mathrm{m}^{2} / \mathrm{day}\right)\end{array}$ & $\begin{array}{c}\text { Oxygen Permiability } \\
\left(\mathrm{cm}^{2} \mu \mathrm{m} / \mathrm{m}^{2} \mathrm{dkPa}\right)\end{array}$ \\
\hline $0 \%$ & $0.096 \mathrm{c}$ & $101.75 \mathrm{~d}$ & $2.63 \mathrm{~d}$ & $94.20 \mathrm{a}$ & $852.00 \mathrm{a}$ & $0.35 \mathrm{c}$ \\
$10 \%$ & $0.100 \mathrm{~b}$ & $112.60 \mathrm{~d}$ & $4.57 \mathrm{c}$ & $92.18 \mathrm{ab}$ & $780.51 \mathrm{~b}$ & $0.70 \mathrm{~b}$ \\
$15 \%$ & $0.109 \mathrm{~b}$ & $138.25 \mathrm{c}$ & $5.10 \mathrm{bc}$ & $90.86 \mathrm{c}$ & $632.82 \mathrm{c}$ & $1.03 \mathrm{a}$ \\
$20 \%$ & $0.110 \mathrm{~b}$ & $150.91 \mathrm{~b}$ & $7.17 \mathrm{~b}$ & $90.46 \mathrm{c}$ & $620.82 \mathrm{~cd}$ & $1.17 \mathrm{a}$ \\
$25 \%$ & $0.125 \mathrm{a}$ & $182.66 \mathrm{a}$ & $10.39 \mathrm{a}$ & $90.25 \mathrm{c}$ & $620.53 \mathrm{~d}$ & $1.30 \mathrm{a}$ \\
\hline
\end{tabular}

The same notation in the same column does not show a significant difference $(\alpha=0.05)$ 
Table 2. The average weight of dodol and the presence or absence of fungi during storage of 6 days

\begin{tabular}{lccccccccc}
\hline & \multicolumn{9}{c}{ Storage } \\
\cline { 2 - 9 } Treatment & \multicolumn{2}{c}{ 0 day } & \multicolumn{2}{c}{ Two days } & \multicolumn{2}{c}{ Four days } & \multicolumn{2}{c}{ Six days } \\
\cline { 2 - 10 } & Weight $(\mathrm{g})$ & Fungi & Weight $(\mathrm{g})$ & Fungi & $\begin{array}{c}\text { Weight } \\
(\mathrm{g})\end{array}$ & Fungi & $\begin{array}{c}\text { Weight } \\
(\mathrm{g})\end{array}$ & Fungi \\
\hline $\mathrm{A}$ & 32,2 & negative & 31,9 & negative & 31,9 & negative & 30,4 & negative \\
$\mathrm{B}$ & 32,4 & negative & 32,1 & negative & 32,1 & negative & 31,2 & negative \\
$\mathrm{C}$ & 32,6 & negative & 32,2 & negative & 32,2 & negative & 31,7 & negative \\
$\mathrm{D}$ & 32,8 & negative & 32,6 & negative & 32,5 & negative & 31,9 & negative \\
$\mathrm{E}$ & 32,2 & negative & 32,1 & negative & 32,1 & negative & 32,0 & negative \\
\hline
\end{tabular}

\section{Edible Film Application on Dodol}

Edible film applications carried out in the study include the ability to wrap and dehydrate to replace non-edible packaging. Application to dodol was conducted by cutting edible film sheets according to their size. The packaging printed with the help of pressing the heating system at $180^{\circ} \mathrm{C}$ and pressure using a sealer with a pressing time of 3 seconds. The bag formed is then filled with dodol which has been cut. The difficulty in forming a dodol wrapper it is the sticky nature of the film that makes it difficult to handle in sealing and wrapping. These results were influenced by the materials used, namely sago starch, pectin and glycerol which has the characteristics to absorb water quickly that resulted in a surface that is wet and sticky. Aside from being difficult at the time of application, it also has an adverse effect on stored materials, especially materials that are sensitive to moisture. The dodol used is sticky rice dodol obtained by the local business. To decrease the water content, the dodol was put in the oven at $60-65^{\circ} \mathrm{C}$ for 12 hours. The Dodol was then cut into a rectangle with a size of $5 \mathrm{~cm} \times 3 \mathrm{~cm}$ with weighs $30 \mathrm{~g}$. Dodolwas then put into an edible film box that had been formed and then stored at room temperature for six days. The weighing was done every two days. The results of the weighing were shown in Table 2.

In Table 2, it can be seen that up to 4 days of storage of dodol packed with the edible film had not experienced significant deterioration. However, after six days of storage, there was a significant decline. This was due to edible film which has not only an excellent mass oxygen transmission properties so that water evaporation occurs through the packaging film during storage but also a good oxygen barrier. This was indicated by the absence of fungal growth on the surface of dodol. The same thing was reported by Layuk and Layuk (2016), that the application of edible film on processed zalacca could limit the weight reduction of zalacca significantly. Sago starch edible film with the addition of nutmeg pectin can be applied to products that are susceptible to oxygen and have low to moderate water activities, such as processed, baked products and the confectionery industry. In addition to processed products, it can also be applied to fresh fruits and vegetables to slow respiration rate and extend product shelf life (Sunarti and Layuk, 2010). Edible film applications from pectinates have been applied to peanut products as carriers of antioxidants, salts and dyes (Swenson et al., 1953).

\section{CONCLUSION}

Sago starch can be used as an ingredient in making edible films that can be used as biodegradable packaging and can even be consumed. Addition of nutmeg pectin and glycerol to edible sago films not only can improve thickness, solubility, tensile strength and extension of the film but also can control mass transfer and oxygen. The best treatment is the addition of $25 \%$ nutmeg pectin to edible films which have the highest thickness, tensile strength and extension. Edible sago film is a good oxygen barrier compared to synthetic films. Edible sago films are suitable to be applied as primary packaging for low to moderate water content products such as chocolate coatings, baked products, dodol packaging, fruits and the confectionery industry.

\section{REFERENCES}

ASTM. 1988. Standard test method for oxygen gas transmission rate through plastic film and sheeting using a coulometric sensor D 3985 in Annual Book of American Standard Testing Methods, Philadelphia, PA. 
Banker, G.S., A.Y. Gore, and J. Swarbrick. 1966. Water Vapor transmission properties of free polymer films. Journal of Pharmacy and Pharmacology 18: 457-466. DOI: 10.1111/j.2042-7158.1966.tb07906.x

Balitbangtan. 2015. Inovasi teknologi Pasca Panen Pertanian Bioindustri. BB Pascapanen Pertanian. Kementerian Pertanian.

Fennema, O.R. 1985. Water and Ice. Di dalam Fennema, O. R. (ed). Food Chemistry Marcel Dekker, Inc., New York.

Gennadios, A., A.H. Brandenburg, C.L. Weller, and R.F. Testin. 1993. Effect of $\mathrm{pH}$ on properties of wheat gluten and soy protein isolate films. Journal of Agricultural and Food Chemistry 41: 1835-1839. DOI: 10.1021/jf00035a006

Gulbert, S. 1986. Technology and Application of Edible Film Protective Films. In food Packaging and Preservation, M. Mathlouthi (ed). pp. 213-233. Elsevier Science Publishing Co. Inc. New York.

Gontard, N. and S. Guilbert. 1992. Bio Packaging.: Tecnology and Properties of Edible and/or Biodegradable Material of Agricultural Origin. Food Packaging and Preservation. The AVI Publ. Inc., Westport Connecticut.

Gontard, N., S. Guilbert, dan J.L. Cuq. 1993. Water and glycerol as plasticizers affect mechanical and water vapor barrier properties of an edible wheat gluten film. Journal of Food Science 58: 206-211. DOI: 10.1111/j.1365-2621.1993.tb03246.x

Gomez, K.A. and A.A. Gomez. 1984. Statistical Procedures for Agricultural Research. John Wiley and Sons, New York.

Hay, P.M. 1986. Properties and Methods of Identification of Commercial Films. The Science and Technology of Polymer Film Interscience. London.

Heralp T.J., R. Gnanasambandam, B.H. McGuire, and K.A. Hachmeister. 1995. Degradable wheat gluten film preparation, properties and applications. Journal of Food Science 60: 1147-1150. DOI: $10.1111 / \mathrm{j} .1365-$ 2621.1995.tb06311.x

Krochta, J.M. 1997. Edible composite moisturebarrier films. In Packaging Yearbook 1996. B. Blackstone (Ed). p. 38-54. National Food Processors. New York.

Krochta, J.M., E.A. Baldwin, and M.O. NisperosCarriedo. 1994. Edible coating and films to
Improve Food Quality. Ils ed.Tecnomic Publishing Co. Lancaster, P.A.

Layuk, P. 2001. Karakteristik Edible Film Komposit Pektin Daging Buah Pala (Myristica fragrans Hout) dengan Tapioka. Tesis. UGM Yogyakarta.

Layuk, P., D.W. Marseno, and Haryadi. 2002. Characterization of edible film composite made of pectin from nutmeg mesocarp and tapioca. Jurnal Teknologi dan Industri Pangan 13: 178-183.

Layuk, S. dan P. Layuk. 2016. Biodegradable film dari pati jagung dan penerapannya pada buah salak. Bulletin Agroteksain.

Linsdsay, R.C. 1985. Food additives di dalam Fennema, O.R. (ed). Food Chemistry. Marcel Dekker. INC. New York.

McHugh, T.H. and J.M. Krochta. 1994. Water vapor permeability properties of edible whey protein-lipid emulsion film. Journal of the American Oil Chemists' Society 71: 307312. DOI: $10.1007 / \mathrm{BF} 02638058$

McHugh, T.H., J.F. Aujard, and J.M. Krochta. 1994. Plasticized whey protein edible films: Water vapor permeability properties. Jorunal of Food Science 59: 416-419. DOI: 10.1111/j.1365-2621.1994.tb06980.x

McHugh, T.H. and J.M. Krochta. 1994. Sorbitol VS glycerol plasticized whey protein edible film integrated oxygen permeability and tensile strength evaluation. Journal of Agricultural and Food Chemistry 42: 841845. DOI: $10.1021 /$ jf00040a001

Park, H.J., C.L. Weller, P.J. Vergano, and R.F. Testin. 1993. Permeability and mechanical properties of cellulose-based edible film. Journal of Food Science 58: 136-1370. DOI: 10.1111/j.1365-2621.1993.tb06183.x

Polnaya, F.J., Haryadi, and D.W. Marseno. 2006. Edible film characterizations from native and medication sago starch. Agritech 26: 179-185.

Polnaya, F.J., J. Talahatu, Haryadi, and D.W. Marseno. 2012. Properties of biodegradable films from hydroxypropyl sago starches. Asian Journal of Food and Agro-Industry 5: 183-192.

Sayaka, B. 2016. Industri dan Pemasaran Pangan Lokal. Dalam Pangan Lokal, Budaya, Potensi dan Prospek Pengembangan. IAARD Press.

Slade, L. and H. Levine. 1991. Beyond water activity recent advances on an alternative 
approach to the assessment of food quality and safety. Critical Review in Food Science and Nutrition 30: 115-360.

Sunarti, P., dan P. Layuk. 2010. Mempelajari sifat mekanik dan barrier edible film dari pati jagung. INFOKES-Jurnal Ilmu Kesehatan 4: 97-102.

Swenson, H.A., J.C. Miers, T.H. Schultz, and H.S.

Owens. 1953. Pectinate and pectate ISSN 2302-9218 (Print) ISSN 2620-9721 (Online)

coatings. II. Application to nuts a fruit product. Food Technology 16: 232-235.

Wattimena, D., L. Ega, and F.J. Polnaya. 2016. Characteristics of edible film from native and phosphate sago starches with the addition of glycerol. Agritech 36: 247-252. DOI:10.22146/agritech.16661 